995. On the Application of Trinomial Nomenclature to Zoology. By Dr. Elliot Coues. Ibid., July, r884, pp. 24r-247.-Dr. Coues's address on this subject before National Academy of Sciences in Washington, April, I 884 .

996. Sabine's Gull in Dublin Bay. By J. J. Dowling. Ibid., Dec. Is\&4, p. 490.-A specimen ir the first year's plumage was taken at Cloutarf, Nov. 5, I 884 .

997. The American Killdeer Plover in Cornwall. By Thomas Cornish. Ibid., IX, March, I885, p. I13.-A specimen of Agialitis vociferus shot at Tresco, in the Scilly Islands, Jan. I5, ISS5.

998. Reported Occurrence of the Blue-winged Teal near Redcar. By T. H. Nelson. Ibid., p. I13.-A specimen previously recorded (Zoologist, r882, p. 92) by the same writer as querquedula discors proves to have been a young Garganey ( 2 . circia).

999. Notes on Birds of Manitoba. By Robert Miller Christey. Ibid., April, I 885 , pp. I 2 I-I33.-Interesting field notes on about 45 species.

rooo. Notes on the Zoology of Manitoba. By the late T. B. Wood. (Communicated by J. H. Nelson.) Ibid., June and July, r885, pp. 224227, 241-247.-Extracts from letters to Mr. Nelson, giving various interesting notes.

IOOI. Bartram's Sandpiper.... in Cornwall. By H. E. Dresser. Ibid., p. 232.-Record of a specimen shot "as already recorded in the 'Zoologist,'," several years previously on the cliffs near Coverack.

1002. Discovery of the Eggs of the Knot, Tringa canutus.-By J. E. Harting. Ibid., Sept. $188_{5}$, p. 344--Referring to Dr. C. Hart Merriam's record in 'The Auk' (II, p. 3I2), and stating that "Sabine found the Knot breeding in abundance on Melville Island" in I820, and that "Capt. Lyons found it breeding near Quilliam Creek, Melville Peninsula," in IS23. Reference is also made to Sir John Richardson's reporting "the

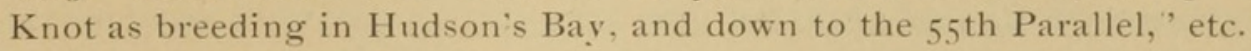

Publications Received.-Bicknell, Eugene P. A Study of the Singing of Our Birds. (Auk, 1884, I885.)

Harvie-Brown, J. A., J. Cordeaux, R. M. Barrington, G. A. Ware, and W. Eagle Clarke. Report on the Migration of Birds in the Spring and Autumn of $\mathrm{ISS}_{4}$. Sixth Report. (Vol. II, No I.)

Merriam, C. Hart. Department of Agriculture, Division of Entomology, Circular No. 20.

Riley, C. V. Department of Agriculture, Division of Entomology. Circular No. is.

Ridgway, Robert. Some Emended Names of North American Birds. (Proc. U. S. Nat. Mus. VIII, No. 23, Sept. 2, 1 885 , pp. 354-356.)

Shufeldt, R. W. On the Coloration in Life of the Naked Skin-tracts on the Head of Geococcyx californianus. (Ibis, 1885 , pp. 286-288, pl. vi.)

Nelson, E. W. Counter-'Notes on some species of Birds attributed to Point Barrow, Alaska.' (Auk, II, pp. 239-24I.

Stephens, F. Notes of an Ornithological trip in Arizona and Sonora. (Auk, II, pp. 225-23I.) 
Zeledon, Catalogue of the Birds of Costa Rica, indicating those Species of which the United States National Museum possesses specimens from that Country. (Proc. U. S. Nat. Mus., VIII, Nos. 7, 8, pp. I04-II8, May, I885.)

Agassiz Journal (Lynn, Mass.), I, No. 3. Aug. 1885.

American Field, XXIII, Nos. 25, 26, XXIV, Nos. I-I 2.

American Naturalist, Aug. Sept. Oct. 1885 .

Anzeiger, Zoologischer, Nos. 197-203, 1885 .

Bulletin Des Moines Acad. Sci., I, No. I, March, I885.

Bulletin Essex Institute, XVII, Nos. [-3, Jan.-Mar. 1885 .

Bulletin U. S. Fish Commission, V, Nos. 7-21, 1885 .

Canadian Science Monthly, III, June, July, I885.

Forest and Stream, XXIV, Nos. 2I-26, XXV, Nos. I-8, I885.

Hoosier Naturalist (Valparaiso, Ind.), I, Nos. I, 2, Aug. Sept. I885.

Journal Cincinnati Soc. Nat. Hist. VIII, No. 2, July I 885.

Kansas City Review, IX, No. I, Aug. I885.

Monatsschrift des Deutschen Vereins zum Schutze der Vogelwelt, IX, Nos. 9-I 2, I884, X, Nos. I-5, 1885 . (From H. Nehrling.)

Museum, The, I, No. 3, July, I885.

Naturalist, The, A Journ. Nat. Hist. for the North of England, Nos. I 2OI22, July-Sept. I885.

Naturalists' Companion (Brockport, N. Y.), I, Nos. I, 2, July, Aug. I 885 .

Ornithologist and Oölogist, X, Nos. 8, 9.

Proceedings Biolog. Soc. Washington, II (July I, I882, to July I, I884), 1885.

Proceedings Nat. Hist. Soc. Glasgow, V, pt. 3, I884, I (New Series) pt. I, I885.

Random Notes on Natural History, II, Nos. 7-9, I885.

Transactions Kansas Acad. Sci., IX, I885.

Ward's Nat. Sci. Bulletin, III, Nos. I, 2, Jan. July I $88_{4}$.

Zoologist, July, Aug. Sept. I885.

\section{GENERAL NOTES.}

Kirtland's Warbler from the Straits of Mackinac. - In a lot of birds sent me by William Marshall, Esq., keeper of the light-house on Spectacle Reef, Michigan, is a male specimen of Kirtland's Warbler (Dendraca kirtlandi). It killed itself by striking the light at that place on the night of May 21, I88.5. Found with it, dead at the foot of the tower, were Turdus mustelinus, Dendraca blackburnia, D. maculosa, Siurus auricapillus, Passerculus savanna, and Tringa minutilla. Spectacle Reef is in the western part of Lake Huron near the Straits of Mackinac, midway between the north and south shores.-C. Hart Merriam, Locust Grove, $N$. $r$. 


\section{$2 \mathrm{BHL}$ Biodiversity Heritage Library}

1885. "Publications Received." The Auk 2, 375-376.

https://doi.org/10.2307/4625307.

View This Item Online: $\underline{\text { https://www.biodiversitylibrary.org/item/54093 }}$

DOI: https://doi.org/10.2307/4625307

Permalink: https://www.biodiversitylibrary.org/partpdf/86923

\section{Holding Institution}

Smithsonian Libraries

\section{Sponsored by}

Smithsonian

\section{Copyright \& Reuse}

Copyright Status: Public domain. The BHL considers that this work is no longer under copyright protection.

This document was created from content at the Biodiversity Heritage Library, the world's largest open access digital library for biodiversity literature and archives. Visit BHL at https://www.biodiversitylibrary.org. 